\title{
Trauma and Affective Spill
}

\section{EMMA WILLIS}

UNIVERSITY OF AUCKLAND

\author{
Bryoni Trezise \\ Performing Feeling in Cultures of Memory \\ Palgrave Macmillan, London, 2014 \\ ISBN 9781137336217 RRP $£ 55.00$
}

After finishing Bryoni Trezise's erudite book about the performance of feeling in cultures of memory, there were several questions that lingered for me as someone also interested in the relation between aesthetics and violence. Some of those questions are easier to put than others. How do we construct aesthetic responses that hold violent structures and ideologies to account without 'doing violence' to the spectators of those depictions? Or must spectators be exposed to violence in some way to have their political and ethical consciousness raised? If the latter, what do we make of our affective complicity in economies of violence? Trezise's book takes on

ISSN 1837-8692

Cultural Studies Review 2015. @ 2015 Emma Willis. This is an Open Access article distributed under the terms of the Creative Commons Attribution 4.0 Unported (CC BY 4.0) License

(https://creativecommons.org/licenses/by/4.0/), allowing third parties to copy and redistribute the material in any medium or format and to remix, transform, and build upon the material for any purpose, even commercially, provided the original work is properly cited and states its license. 
the quandaries that oscillate around the memorialisation and performance of histories of violence in a way that not only scrutinises the operation of cultures of memory but also provides a significant point of departure for understanding these practices in affective terms.

While Trezise comes from a theatre and performance studies background, the case studies she traverses cover a wide-range of modalities and mediums: concentration camp memorials, the Tjapukai Aboriginal Cultural Park, the television series Crossing Over with John Edward, the United States Holocaust Memorial Museum's online memorial, the virtual Kristallnacht that exists in Second Life and, finally, Italian theatre company Socìetas Raffaello Sanzio's performance Tragedia Endogonia Br. \#04 Bruxelles. In each case study, Trezise examines the role of affect in meeting the challenge of remembering the victims and perpetrators of violence without turning violent histories into affective spectacles that enable spectators 'to affirm their own domain of moral self-certainty'. (41) While this ethicalrepresentational tension has been widely addressed in the fields of trauma studies, memory studies, Holocaust studies and performance studies, Trezise brings to the established conversation a new and highly detailed reading of affect theory coupled with insight from her background in theatre studies. Her rigorous interrogation of the manner in which cultural meaning is generated through feeling bodies places the experiencing body at the centre of the inquiry.

The concept what she terms the 'memory affect' is at the core of Trezise's arguments. Drawing on Sara Ahmed's account of emotions as cultural practices not psychological states, Trezise understands feeling as a process of 'self-making' that is 'interactive' in so far as it is carried out in relation to other bodies and objects. Specifically, Trezise asserts that feelings are 'memory practices that have, and are, particular cultural affects'. (3) The recent ANZAC memorial 'celebrations' are a vivid exemplar for Australasian readers of the way in which emotional affects are mobilised towards the construction of individual and national identity. The stifling of dissent related to marking the centenary powerfully illustrates the political mobilisation of feeling through popular participation in events that engage spectators primarily through sentiment. Consider Gallipoli: The Scale of our War, now on free exhibition at Te Papa Tongarewa in Wellington, New Zealand, as one such example. A collaboration between Te Papa and Weta Workshop, the digital 
special effects studio founded by Peter Jackson, the exhibition features a number of ultra-realist sculptures of soldiers scaled 2.4 times bigger than life. Visitors are immersed in a world of giants, an experience that amplifies the emotional intensity of the one-on-one encounter between figure and spectator that is the primary element of the exhibition. The more-real-than-real fake figures illustrate the problem that Trezise identifies in similar endeavours where 'unthinking feeling' (6) comes to dominate the museum experience. Trezise's use of the term 'memory affect' is a particularly helpful naming of the phenomenon in operation at many memorial and museum sites in which affect becomes a commodified experience in the form of 'feel-able, bite-sized anecdotes of suffering designed to be absorbed between a hotel breakfast and an afternoon jug of beer'. (54)

Of particular interest to Trezise are instances of 'affective spill' where a kind of meta-affectivity comes into play-moments when spectators are able to perceive the affective circuits of feeling that are usually opaque within memorial settings. As an example of 'affective spill' Trezise uses Jane Korman's Dancing Auschwitz project, which features among other components a video of the artist's grandfather and family members dancing at Auschwitz to the soundtrack of Gloria Gaynor's disco anthem 'I Will Survive'. Korman's response to the Holocaust strikingly transgresses memory affect's normative emotional script. By 'treading on the graves', as Trezise describes it, 'Dancing Auschwitz makes what might have otherwise been the unconscious contradictions of smiling while mourning, of photography of the sacred, of indecent gestural codes, visible and empowering'. (54) Such moments of metaaffective spill effect a paradigmatic shift that can be summarised as 'de-remediating the memory affect' thereby enabling 'memory's affectivity to be meta-affectively reperceived'. (139) Throughout the book, Trezise draws directly on her own experiences as spectator to illustrate when spill occurs. This autoethnographic element is a strength of the book since Trezise reperforming her responses to various sites triggers the reader's response as bystander to her account. Indeed, one of my only quibbles with the book is that she might have made more of this secondorder spill.

The chapter on the Tjapukai Aboriginal Cultural Park is a surprising progression after the more familiar examples relating to the Holocaust and provides a completely different set of coordinates from which to consider the enmeshment of 
cultural history and affective practices. Trezise convincingly argues that the historical world presented at Tjapukai 'is used to evade and replace the traumas of colonial Australia with a popularized form of ancient cultural memory'. (57) While this substitution is not uncommon to countries with a colonial past, the Aboriginal concept of Dreamtime underpins the performance of timelessness at Tjapukai. Within the enacted narrative indigeneity operates metonymically with the Aboriginal subject transformed into a 'symbol of a continuous act of timeless recall.' As Trezise underscores, such symbolic practices of remembering enable a culture of forgetting. But, as elsewhere, Trezise goes on to give an account of her evening at Tjapukai that concentrates on a moment of affective spill. Near the end of the evening, at a crucial 'ceremonial' moment, the fire failed to light. The effect of the failure was the revelation of the constructedness of the performance, which generated its own complex of responses:

Feeling otherwise to the moment of performance here generated affective

plurality and perhaps even surprise at the spectre of the rather ordinary,

less than pyrotechnic, less than fluorescent, man before us. (77-8)

Building from this experience, Trezise ends the chapter by calling for a dramaturgy that 'stages a place of potentiality' that would 'harness the accidental affects that percolate at the edges of this tired, and tightly bursting scripted repertoire'. (78) What might such a dramaturgy look like? I wonder if including examples of the work of Indigenous artists might suggest the ways in which many Indigenous peoples, including those engaged by tourist operations such as Tjapukai, have long since moved away from situations of bathos to the staging of a 'continuing affective state of becoming other-wise'. (78) The different cultural, historical and political coordinates at play at a site such as Tjapukai illustrate the problem with deploying a term like memory affect across such a broad spread of examples. Had the chapter on Tjapukai incorporated Aboriginal points of view, the analysis might have been productively challenged and enriched. That said, the fact that Trezise extends her inquiry to address Tjapukai makes a valuable contribution to cultural tourism studies and postcolonial studies.

If Trezise's account of Tjapukai depicts a kind of spectral conversation that draws together the distant figures of an ancient past with contemporary spectators, then her next chapter on psychic medium John Edward's televised stage show, 
Crossing Over with John Edward, brings together the more recently departed and their kin. The chapter charts the complex intersections of phenomenal disappearance and reappearance, examining the real effects (and affects) of the ghosts conjured by Edward's performances. Trezise considers how events such as Crossing Over 'mobilize late capitalist models of subjecthood that affirm personal trauma as a publicly available form of sociality, whilst at the same time using it to promise a future without trauma'. (80) The notion of persona trauma as a 'form of sociality' integral to the construction of the neoliberal subject, is one of the most compelling arguments of the book. The growing scholarship on what is variously called thanatourism, dark tourism or grief or trauma tourism, illustrates a mass phenomenon that is characterised by an engagement with experiences that produce 'deathly' affects or a more general willingness to open oneself to psychological or emotional wounding by association. Building on the work of Tony Seaton, Philip Stone and Richard Sharpley have argued that what tourists seek at deathly sites is the ontological security that comes from death's incorporation into normal social life, an experience otherwise missing from the contemporary era where, like everything else, death has been contracted out. ${ }^{1}$ While this notion of ontological security bears some relation to the 'moral self-certainty' Trezise identifies at play in concentration camp memorials, her discussion of the affective pull of Edward's performances mostly involve 'a felt absence of feeling'. (82) This is vividly illustrated by the desperation of the participants in Crossing Over to make a connection with the dead. Despite the show's banal production of 'consumable trauma', (95) what is truly haunting about it, Trezise suggests, is its testimony to the 'loss of loss'. (85)

The next chapter moves from the televisual to the virtual with the example of Kristallnacht in Second Life, which illustrates the spatial, psychological and political contours of the online museum not least by requiring the visitor to construct an avatar. Trezise begins by pointing out the strong tendency for virtual museums to recreate the familiar tropes of existing museums and memorials, an observation that also proves true in the affective domain: "memory culture in "Second Life" could be seen to participate in the continued circulation of a range of problematic "wound culture" affects, such that it ... serves the moral certitude of the spectator as witness over the subject being recollected'. (109) What is original to virtual domains, however, is their timeless or deathless aspect. That is, the materiality of the virtual is 
identical to both historical subject and the avatar assumed to enter the memorial space. Unlike other performative encounters commemorating historical atrocities, subject and spectator are commonly composed in the shared space of the virtual. As Trezise points out, 'virtual traumas are those cultural texts that have been produced by digital media in response to traumatic events, but are also importantly, the constitution of those events specifically through, and as, digitisation'. (116) Yet, once again, it is in the space of affective disruption, here characterised as affective indifference', that Trezise locates the ethical potential of virtualised memorial spaces. Specifically, the affective indifference that follows the distanciation of certain aspects of Kristallnacht in Second Life enables Trezise to 'sense myself as a feeling being'. (135) No matter its virtual original, affective indifference directs attention back to embodied feeling.

It is the materiality of the body to which Trezise turns in her final chapter on Socìetas Raffaello Sanzio's performance, Tragedia Endogonia Br. \#04 Bruxelles. Trezise's background as a theatre scholar comes to the fore in this chapter and allows her to skilfully advance the overall argument of the book. At its heart is a description of the main action of \#04 Bruxelles, which is the enactment of the beating of an anonymous man. Trezise focuses on the painfulness of watching the beating, which was both clearly staged and at the same time affectively overwhelming in its 'realness'. In particular, she recalls the amplified sound of the rubber baton hitting the body. As a reader, I found compelling the way the viscerality of the sound 'spilled' across media, creating what theatre scholar Caroline Wake describes as a kind of tertiary witnessing in the reader through the evocation of the effect of the performance on the original spectator. ${ }^{2}$ Trezise writes that the effect of the beating was a kind of 'affective listening' (154) where her own 'sensorial subjectivity' (155) was revealed. She notes that many spectators walked out of the performance, unable to cope with the 'pain' of acting as witness to such a violent spectacle. Trezise stayed to the end of the performance and subsequently recalls in writing her self consciousness as a spectator who hears herself hearing and feels herself feeling: 'What happens here is a startling process by which, through affect, I simultaneously perceive affect as well as its affect-effects, at work.' (155) It is precisely this transformation of perception-enabled through aesthetic processes grounded in an affectively oriented performance practice - that Trezise has been in 
pursuit of throughout the book. This is 'spectatorship that hurts' and its pain is of an altogether different character to that provided by those commodified trauma experiences that reassure the self-certain subject of the moral landscape on which they stand and feel.

Trezise's arguments are highly complex and her analysis of the centrality of memory and trauma affects to the construction of selfhood in a neoliberal and increasingly technologically mediated era is compelling. The book not only identifies the phenomena of 'feeling in cultures of memory' but also begins to move towards thinking beyond this regime. To end, let me return to one of the questions I raised at the outset of this review: is it possible to hold violent structures and ideologies to account without 'doing violence' to spectators through an aesthetics of assault? In Dissensus: On Politics and Aesthetics, Jacques Rancière, drawing on Bertolt Brecht's writing, suggests that the language of ethics woven through contemporary art and politics is underpinned by a logic whereby 'only violence helps where violence reigns'. ${ }^{3}$ (186) This ethos is characterised by the kind of affective cultures that Trezise decribes where, in Rancière's words, 'the time turned towards an end to be accomplished-progress, emancipation or the Other-is replaced by that turned towards the catastrophe behind us'. $^{4}$ The result is an aesthetic practice that compulsively performs the 'endless work of mourning'. ${ }^{5}$

The image given on the cover of Trezise's book gives a partial reply to the bind Rancière identifies. It features a still from the video recording of Korman's I Will Survive, which shows her father and three of his grandchildren dancing at Auschwitz. Korman's father wears a shirt emblazoned 'survivor' and smiles directly at the camera. Alongside him, three of his grandchildren dance in profile each wearing shirts that read 'third gen'. Even in freeze-frame this image captures the joy of life, its persistence and literal regeneration, alongside the loss that makes it all the more palpable. Here the long reach of pain is acknowledged yet overcome in an unwillingness to defer to another economy of feeling. \#04 Bruxelles, on the other hand, creates a violent present in which the unbearableness of the beating shatters spectatorial complacency through a concurrent absorption in and repellence from the action. In the end, I wonder if the case made by Trezise's book isn't for the necessity of both integrative and shattering aesthetics, and the restless, relentless movement that can be traced between them. 
Emma Willis is a lecturer in drama at the University of Auckland. Recent publications include Theatricality, Dark Tourism and Ethical Spectatorship: Absent Others (2014); 'Emancipated Spectatorship and Subjective Drift: Understanding the Work of the Spectator in Erik Ehn's Soulographie', Theatre Journal, no. 66, 2014; 'Makeshift Memory: Engaging an Aesthetic of Transition', Ekfrase: Nordic Journal of Visual Culture, no. 2, 2014 and 'A Thousand Hills: Responding to the Ethical Nightmare', Australasian Drama Studies, no. 66, 2015.

\section{-NOTES}

1 Philip Stone and Richard Sharpley, 'Consuming Dark Tourism: A Thanatological Perspective', Annals of Tourism Research, vol. 35, no. 2, 2008, p. 575.

2 Caroline Wake, 'The Accident and the Account: Towards a Taxonomy of Spectatorial Witness in Theatre and Performance Studies', in Bryoni Trezise and Caroline Wake (eds), Visions and Revisions: Performance, Memory, Trauma, Museum Tusculanum Press, Copenhagen, 2013.

3 Jacques Rancière, Dissensus: On Politics and Aesthetics, Continuum, London, 2010, p. 186.

4 Ibid., p. 192.

5 Ibid., p. 200.

\section{-BIBLIOGRAPHY}

Rancière, J., Dissensus: On Politics and Aesthetics, Continuum, London, 2010.

Stone, P. and R. Sharpley, 'Consuming Dark Tourism: A Thanatological Perspective', Annals of Tourism Research, vol. 35, no. 2, 2008, pp. 574-95. doi: http://dx.doi.org/10.1016/j.annals.2008.02.003

Wake, C., 'The Accident and the Account: Towards a Taxonomy of Spectatorial Witness in Theatre and Performance Studies', in B. Trezise and C. Wake (eds), Visions and Revisions: Performance, Memory, Trauma, Museum Tusculanum Press, Copenhagen, 2013, p. 33-56. 